\title{
355. Zur Wirksamkeit von Fibrinogen und Thrombin bei der Deckung experimenteller Verbrennungswunden
}

\author{
R. Ascherl, G. Schäfer, K. Geißdörfer, W. Erhardt, W. Vaillant ${ }^{1}$ und G. Blümel \\ Institut für Experimentelle Chirurgie der TU München, Ismaninger Straße 22, D-8000 München 80 \\ (Dir.: Prof. Dr. G. Blümel), und ${ }^{1}$ Institut für Vorsorgemedizin (Dir.: Prof. Dr. Ing. Dr. med. W. Vaillant) \\ der Technischen Universität München
}

\section{Efficacy of Fibrinogen und Thrombin in Skin Transplantation for Experimental Burn Injuries}

\begin{abstract}
Summary. Experimental burn injuries in the dorsal thoracolumbar region of rats were covered by skin mesh grafts. In the treated group, fibrin adhesive (Tissucol) was also applied. Fourteen days after transplantation planimetric localization of the remaining wound area, microangiographic, histologic and thermographic studies demonstrated a better healing of the transplant additionally treated with fibrin adhesive. This can be explained by the fibrin-initiated contact with the wound and the hemostyptic effect of the fibrin adhesive.

Key words: Burn injuries - Mesh graft - Fibrin glue.

Zusammenfassung. Experimentelle Verbrennungswunden an der Rückenhaut von Ratten $(n=20)$ im Bereich des thoracolumbalen Übergangs wurden mit Haut-Mesh-graft gedeckt, wobei in der Versuchsgruppe zusätzlich Fibrinkleber (Tissuecol) verwendet wurde. Planimetrische Auswertungen der nach 14 Tagen verbleibenden Wundflächen sowie mikroangiographische, histologische und thermographische Untersuchungen zeigen ein verbessertes Einheilen des Transplantates bei gleichzeitiger Fibrinkleberapplikation, was durch den festen initialen Kontakt zum Wundgrund und die verbesserte Blutstillung erklärt werden kann.
\end{abstract}

Schlïsselwörter: Verbrennung - Mesh-Graft - Fibrinkleber.

\section{Das Blutungsrisiko der Thromboseprophylaxe in der Allgemeinchirurgie. Vergleiche von Low-dose-Heparin mit Heparin-Dihydergot 2500}

\section{J. Ammann}

Chirurgische Klinik, Thurgauisches Kantonsspital Münsterlingen, CH-8596 Münsterlingen

\section{Bleeding Complications of Prevention of Thromboembolism in General Surgery: Comparison of Low-dose-Heparin and Heparin Dihydroergotamine 2500}

Summary. This prospective randomized double-blind study in 500 general surgical patients showed a significant reduction in the occurrence of postoperative wound hematoma and reoperation for hematoma, when to prevent thromboembolism heparin $(2 \times 2500 \mathrm{IU})$ was administered in combination with $0.5 \mathrm{mg}$ dihydroergotamine rather than conventional low-dose heparin $(2 \times 5000 \mathrm{IU})(P=0.002$ and 0.03 respectively).

Key words: Prevention of thromboembolism - Bleeding complications - Low-dose-heparin - Heparin 2500 and dihydroergotamine.

Zusammenfassung. In einer prospektiven randomisierten Doppel-Blindstudie wurde das Blutungsrisiko der Thromboembolie-Prophylaxe anhand von 500 Fällen in der Allgemeinchirurgie untersucht. Bei der Prophylaxe mit Heparin-Dihydergot 2500 ergaben sich signifikant weniger Wundhaematome $(P=0,002)$ und haematombedingte Reoperationen $(P=0,03)$ als mit low-dose-Heparin $2 \times 5000$.

Schliisselwörter: Thromboembolie-Prophylaxe - Blutungsrisiko - Low-dose-Heparin - Heparin-Dihydergot. 